\title{
NOTAS SOBRE EL RETABLO DE SANTA CLARA DE BRIVIESCA
}

\author{
POR \\ AURELIO BARRÓN \\ D. ${ }^{\text {or }}$ en Historia del Arte \\ M. ${ }^{a}$ PILAR RUIZ DE LA CUESTA \\ D. ${ }^{\text {ar }}$ en Historia del Arte
}

\begin{abstract}
The altarpiece of Santa Clara of Briviesca (Burgos) is one of the masterworks of the Spanish Renaissance sculpture. Antonio Ponz and Ceán Bermúdez considered that the work belonged to Gaspar Becerra. Acording to a judicial documentation, this altarpiece had been thought to belong to Pedro López de Gámiz. The finding of a part of the lawsuit that the sculptor had with the Condestable of Castilla, sponsor of the work, and the knowledge of the artistic personality of Diego Guillén and López de Gámiz has permitted us to consider the participation of these artists in the altarpiece and to return to relate the design of the work to Gaspar Becerra; in addition to the participacion of Juan de Anchieta and, perhaps, some eculptors who had arrived from Italy with Becerra.
\end{abstract}

Algunos datos recientes, sobre la realización del retablo del monasterio de Santa Clara de Briviesca (Burgos), permiten hacer nuevas precisiones, aunque aún haya que esperar a que aparezca el grueso del pleito, entre el Condestable de Castilla y el contratista final de la obra, en el archivo de la Real Chancillería de Valladolid o en el archivo de la Nobleza de Toledo.

La calidad excepcional del retablo de Briviesca siempre ha atraído a los historiadores del arte. Al conservarse en blanco permite observar el acabado intachable de la escultura, equiparable a la del retablo mayor de la catedral de Astorga e incluso de calidad superior en muchas de sus imágenes. Contratado a tasación, se realizó concienzudamente y sin apresuramiento. Se había previsto un altísimo precio, 12.000 ducados, que los tasadores confirmaron. Weise y Camón Aznar le han dedicado comentarios muy elogiosos, llegan a defender que supuso en la renovación de la escultura tanto como El Escorial en la arquitectura. A la corrección formal, un tanto fría, de la escultura astorgana se añade una profunda impresión espiritual contenida en la gesticulación grave y arrogante de las imágenes de Briviesca (Fig. 1).

Desde que se diera a conocer la intervención de Diego Guillén y Pedro López de Gámiz en el retablo de Briviesca, diversos autores han recibido con reservas y extrañeza la adjudicación señalada por documentación judicial.

Se negaba todo a Diego Guillén, por entonces desconocido y supuestamente especializado en el trabajo en piedra. Cuando más, se le adjudicaba el banco pétreo, sin reparar que en la piedra se encuentran los mismos estilos que en la madera del retablo. Sobre Gámiz se manifestaban reservas, esperando que se perfilara su personalidad artística, o, dando por buena la atribución, 
se le presentaba como autor fundamental en los inicios del romanismo ${ }^{1}$. Creemos que, a pesar de las aportaciones sobre su biografía artística, queda sin resolver qué parte le cupo verdaderamente en la realización del retablo de Briviesca. La documentación permite rechazar que a él se deba la idea original del retablo - la traza y la concepción de imágenes y escenas- y no es fácil identificar su gubia en las esculturas de Briviesca.

Por nuestra parte, al estudiar la obra de Diego Guillén ${ }^{2}$, presentamos una hipótesis sobre la realización del retablo de Santa Clara que seguimos manteniendo, precisados unos supuestos y confirmados otros con la nueva documentación conocida.

La fundadora del monasterio, Mencía de Velasco, había dejado en un arca de su aposento, en el compás del monasterio de Santa Clara de Medina de Pomar, unos memoriales que contenían «la orden que ha de llevar las dichas cosas [monasterio y hospital de Briviesca] y tambien los retablos", según señaló en el testamento otorgado el 11 de mayo de 1517. Las obras se demoraron y no se siguió el plan original para el retablo mayor. Quedó en blanco, sin dorar ni pintar, a pesar de que las monjas exigieron, en 1593, que se policromara y que se realizaran también los retablos laterales.

En 1546 se había terminado la obra de cantería del monasterio ${ }^{3}$. Consta que se podían celebrar actos religiosos y que hubo una demora de once años en las obras del convento. En fecha imprecisa, se suele suponer sin contraste documental que en torno a 1551, el Condestable -Pedro Fernández de Velasco, testamentario y patrón de las obras del monasterio- se concertó con Diego Guillén para realizar un retablo, conforme a una traza pintada en un papel, que no debía superar los 1.500 o 1.600 ducados. No se puede descartar que el concierto se realizara en 1557 . En todo caso, el retablo se comenzó en fechas próximas a 1560 sin seguir la traza original de Guillén y se aceleró su construcción a partir de 1562, al acabarse el retablo de Astorga.

Por el año 1550, Guillén estaba en la cúspide del éxito. Entre 1546 y 1547 realizó un retablo para Juan Ortega de Velasco, abad de San Quirce, en la capilla de Santiago en la catedral de Burgos. En 1548 contrató la ejecución de un retablo para Riocerezo. En 1550 terminó el retablo mayor de Salas de los Infantes. Poco después realizaba el retablo mayor del monasterio de la Merced de Burgos. Desde 1550 hasta su muerte -en la primavera o verano de 1565- fue maestro de la obra de escultura del colegio de San Nicolás de Burgos cuyo testamentario y patrón era el mismo del monasterio de Santa Clara: el Condestable Pedro Fernández de Velasco. Su taller se encargó de la fachada del Colegio, de los escudos y de las claves. Colaborador de Vigarny, su estilo está impregnado de un clasicismo dulce, deudor tanto del borgoñón como de Diego de Siloé. Lo mejor de su obra denota conocer también el expresionismo berruguetesco. De hecho Diego Guillén y Alonso Berruguete se conocieron y debió existir entre ambos cierta proximidad personal. En septiembre de 1559, Alonso Berruguete apadrinó a un hijo de Diego Guillén que fue bautizado en la iglesia de San Lesmes de Burgos con el mismo nombre de su padre ${ }^{4}$. No sa-

1 Andrés Ordax, S., «El escultor Pedro López de Gámiz», en Goya, n. ${ }^{\circ}$ 129, 1975, pp. 156-167. Idem, El foco de escultura romanista de Miranda de Ebro: Pedro López de Gámiz y Diego de Marquina, Valladolid, 1984. Díez Javiz, C., Pedro López de Gámiz. Escultor mirandés del siglo xvI. Miranda de Ebro, 1985. Idem, "Pedro López de Gámiz en el IV Centenario de su muerte», en López de Gámiz, n. ${ }^{\circ}$ XIX, 1988, pp. 5-36. Echeverría Goñi, P.L.-Vélez Chaurri, J.J., López de Gámiz y Anchieta comparados. Las claves del romanismo norteño", en López de Gámiz, n. ${ }^{\circ}$ XIX, 1988, pp. 37-97 (reeditado en Príncipe de Viana, n. ${ }^{\circ}$ 185, 1988, pp. 477-534. Barrón, A.; Ibarguchi, B.; Ruiz de la Cuesta, M. ${ }^{a}$ P., El escultor renacentista mirandés Pedro López de Gámiz. Miranda de Ebro. 1988. Barrón, A.; Ruiz de la Cuesta, M. ${ }^{a}$ P., «Noticias sobre Pedro López de Gámiz», en Estudios Mirandeses, n. ${ }^{\circ} 12,1992$, pp. 61-71.

2 Barrón, A.; Ruiz de la Cuesta, M. ${ }^{a}$ P., «Diego Guillén, imaginero burgalés (1540-1565)", en Artigrama, n. ${ }^{\circ}$ 10, 1993, pp. 235-272.

${ }_{3}$ Agradecemos a Begoña Alonso, que realiza una investigación sobre los Rasines, las noticias que nos ha proporcionado sobre el monasterio.

${ }_{4}^{4}$ Archivo Diocesano de Burgos, Iglesia de San Lesmes, Libro de bautizados, 1553-1594. 
bemos de cuando data la relación, pero podemos sospechar que Guillén conoció a Berruguete en Toledo, mientras los talleres de Vigarny y Berruguete se encargaban de las obras del coro de la catedral primada. En otro lugar hemos destacado la gesticulación expresiva de las esculturas del retablo mayor de la iglesia de Santa María en Salas de los Infantes 5. Hablamos entonces de un cierto influjo berruguetesco que ahora confirmamos a la luz del suceso señalado arriba.

Las noticias sobre la participación tanto de Guillén como de López de Gámiz en el retablo de Santa Clara proceden de un pleito que la villa de Briviesca y las monjas del monasterio mantuvieron, entre 1574 y 1585, contra el Condestable -primeramente Iñigo Fernández de Velasco y después Domingo Fernández de Velasco- por incumplimiento de algunas mandas de la fundadora, singularmente la tardanza en la realización del hospital, así como la apropiación de rentas del monasterio por parte del Condestable ${ }^{6}$. En el transcurso del pleito se obligó al Condestable a rendir cuentas. En ellas se mencionan los pagos por el retablo y se dan numerosas noticias sobre otro pleito que el Condestable sostuvo con Pedro López de Gámiz, escultor que había finalizado el retablo. Recientemente hemos encontrado algunos papeles sueltos y fragmentarios del pleito con Gámiz que nos permiten hacer la relectura presente 7 .

Como hemos señalado, las obras del monasterio habían concluido, en lo básico, en 1546 y hasta 1557 no debieron emprenderse nuevos gastos, siendo esta fecha y no 1551 -contra lo que se ha escrito- el límite anterior para el inicio de las obras del retablo. El Condestable había argumentado la existencia de un Breve papal por el que podía reservar las rentas durante once años - de 1546 a 1557 - y detener las obras. La inactividad permitió acumular 4.400 .000 maravedís y con ellos pretendía comprar renta para el monasterio, pues sus recursos eran insuficientes para mantenerse. El monasterio exigió judicialmente, a partir de 1574, que entregara el capital señalado para comprar rentas seguras, que comenzaran las obras del hospital y que rindiera cuentas de lo gastado desde 1557, separando los gastos de las obras del costo del retablo.

El Condestable demandado aprovechó para presentar sólo las cuentas de su patronazgo que comenzaban en 1560. Su tío y predecesor, Pedro Fernández de Velasco, había muerto a finales de 1559. Creemos que es significativo, para el inicio de las obras del retablo, que se pidieran cuentas desde 1557, pero nada sabemos de los gastos desde este año ni de los dos siguientes.

En el pleito del hospital se expresó que el Condestable había pagado a Guillén algo más de 900.000 maravedís -2.400 ducados. Diego Guillén dirigió el retablo hasta su muerte, ocurrida a mediados de 1565. La primera referencia al retablo aparece en el descargo de las cuentas del Condestable del al año 1563, aunque se puede deducir, de la manera de apuntar las partidas de los años anteriores y posteriores, que anteriormente los gastos en el retablo se incluían en la referencia genérica a obras en el monasterio. Se puede sospechar que la inclusión de partidas conjuntas fuera intencionada para que parecieran gastos en obras del monasterio y los demandantes no pudieran averiguar las partidas. Así vemos que los litigantes - monjas y peticionarios del hospital- exigieron, sin éxito, que los gastos en el retablo y en las obras del monasterio fueran independientes «no habia de meter los pagos del retablo con otra obra porque no se encubriese la verdadi. Pidieron que se precisara qué obra se había hecho y, minimizando las obras acometidas en

\footnotetext{
5 Barrón, A.; Ruiz de la Cuesta, M. . P., «Diego Guillén..., p. 252.

6 Sanz García, J., «El retablo de Santa Clara de Briviesca. (Estudio documental)", en Boletín de la Comisión Provincial de Monumentos de Burgos, 1934-1937, t. IV, pp. 114, 140, 176, 225, 266, 319, 346.

7 Archivo Foral de Bizkaia, Judicial-Corregimiento, leg. 1.352, n. ${ }^{\circ} 42$. Agradecemos la amabilidad de José Ángel Barrio Loza que nos puso bajo la pista del documento. También lo ha usado José Javier Vélez Chaurri que ha publicado alguna noticia sobre él, Vélez Chaurri, J. J., "Becerra, Anchieta y la escultura romanista", en Cuadernos de Arte español, n. $^{\circ}$ 76. Madrid, Historia 16, 1992, p. 24.
} 
el hospital, rogaron que no se recibiese en el descargo el salario de Pedro de Rasines «como veedor de obras del dicho hospital de la dicha Mencia, porque este nunca se habia hecho ni aun estaba comenzado, y asi era salario impertinente haber veedor y no tener obra». Entre 1560 y 1565 se gastaron en obras 1.208.945 maravedís -3.223 ducados ${ }^{8}$. Buena parte de esta cantidad ha de corresponder con lo recibido por Diego Guillén, pues las obras en el hospital debían ser escasas y la única obra de cantería que se arguyó era la huerta de las monjas.

En el pleito con López de Gámiz, el procurador del Condestable dijo que Guillén había dejado "hechos los dos primeros vancos del retablo de quatro que había de tenen. Aparte del sotobanco de piedra, el retablo actual se compone de banco, cuatro cuerpos y remate -o banco, tres cuerpos, ático y remate- pero el procurador argumentaba sobre los cuatro bancos que tenía la traza original. Entendemos por ello que lo realizado por Guillén era el banco de madera y el primer cuerpo. El propio Gámiz tasó lo realizado por Guillén y lo valoró, en marzo de 1566, en 500.000 maravedís -1.333 ducados, aproximadamente el precio concertado por todo el retablo en el contrato original con Diego Guillén. La diferencia entre los 900.000 maravedís pagados a Guillén y los 500.000 de la tasación pudiera estar en que no se incluyó en lo tasado el banco pétreo ni los escudos de la capilla que, como en el colegio de San Nicolás, le han de pertenecer.

El resto del retablo fue realizado bajo la dirección de Gámiz. Éste precisó que cuando contrató la obra "era mucho mas lo que estava por hazen:: a nuestro entender tres cuerpos y remate. El procurador del Condestable reclamaba porque López de Gámiz no había seguido la traza original. El artista mirandés se defendió señalando que Diego Guillén «no había guardado su propia traza» sino una "planta que tenia hecha, la qual era diferente de la traça». También los tasadores del retablo señalaron que «en ninguna cosa se pareçe a la traça ni la traça al retablo».

En Villalpando, Pedro López de Gámiz contrató la conclusión del retablo el 2 de marzo de 1566. El artista y el Condestable acordaron que se pagara a tasación. López de Gámiz anticipó que costaría 12.000 ducados. Debía seguir la planta del retablo que tenía Guillén y se le había de entregar. Once días después, en Miranda de Ebro, ofreció fianza para el cumplimiento del contrato y se obligó a concluir el retablo en dos años siempre que le entregaran 900 ducados. Esta cantidad se rebasó ampliamente. En las cuentas del mayordomo se registraron, de abril de 1566 a noviembre de 1570, pagos por valor de 5.092 ducados 9. Precisamente, López de Gámiz argumentó, para desmontar la tesis contraria, que el Condestable debía saber el precio del retablo y no extrañarse de la tasación, pues le había anticipado 5.000 ducados mientras lo realizaba.

Contratado a tasación, las esculturas tienen un acabado esmeradísimo. Pudiera ser que López de Gámiz se excediera con labores innecesarias en el retablo. En este sentido se quejaba el procurador del Condestable, aunque hay que estar prevenido contra las argucias de los abogados. Señaló que "hizo el retablo tan conforme a su voluntad que en ninguna cosa siguio [la traza]". Gámiz demostró que no era la traza sino la planta lo que debía continuar. La otra parte le censuraba haber hecho "aun conforme al intento que llevo, muchas cosas impertinentes y costosas y en lugares ascondidos donde no es posible versei.

López de Gámiz no terminó el retablo en el plazo previsto. Por ello, el 4 de octubre de 1569, firmó un segundo contrato de ratificación. En esta ocasión se acordó que el retablo se le abonara en plazos anuales de 300 ducados; esta cantidad se le pagó en los años 1573, 1574 y 1575 , mediando vía ejecutiva, así como en los años sucesivos.

El retablo lo tasó Juan de Juni en 1571. Lo valoró en algo mas de 12.000 ducados. El Con-

8 El resumen del descargo por obras es el siguiente: 1560, 226.399 maravedís; 1561, 352.733; 1562, 192.889; 1563 , $243.555 ; 1564,140.080 ; 1565,53.289$.

9 Entre abril de 1566 y noviembre de 1570, fecha que indica la conclusión del retablo, recibió las siguientes cantidades: 1566, 530.406 maravedís; 1567, 130.488; 1567-1568, 392.305; 1568, 225.000; 1569, 225.000; $1570,256.664$. 
destable recurrió la tasación ante el Alcalde Mayor del Adelantamiento. Aportó una nueva tasación de Juan Bautista Portiggiani. Se sentenció en contra, pero el patrón llevó el pleito ante la Cancillería de Valladolid, pues, sin que haya que dar crédito a los argumentos de su procurador, buscaba una rebaja. Los artistas, por ahorrar pleitos y gastos, solían consentir en el descuento. Gámiz resistió el envite. Era hombre bregado y con aspiraciones de medro social. Estaba casado con María de Frías - miembro de una hacendada familia de Miranda de Ebro- había aspirado a ser regidor de la villa y era procurador general sustituto desde junio de 1564. En la segunda tasación y retasación intervinieron los vallisoletanos Juan de Salamanca, Isaac y Juan de Juni, Alonso Falcón, Sebastián de Burgos; los burgaleses Rodrigo de la Haya, Antonio de Elejalde, Juan de la Secada, Diego de Torres el Joven, Juan Ortiz de Espinosa; Francisco Vázquez, imaginero de Belorado, y Mateo Mingo, vecino de Quintanilla de las Dueñas. El precio final se fijó en 10.000 ducados descontados «mas de dos mil ducados de lo que estaba mandado dar por el dicho retablo».

La documentación encontrada no resuelve el problema de la atribución concreta de las obras. Bajo la dirección de Guillén se realizó una parte fundamental del retablo pero no siguió una traza propia sino una planta que ha de ser de otro. Ni la arquitectura ni la escultura le pertenecen, aunque creemos ver su gubia en algunas imágenes del banco pétreo, del banco de madera y del primer cuerpo.

A López de Gámiz tampoco corresponden ni la traza ni la concepción de las imágenes. Reconoció haber seguido la planta que tenía Guillén. El estilo del retablo es tan unitario que ha de haber unas mismas manos de principio a fin, tanto en la parte dirigida por Guillén como en la dirigida por Gámiz. Pudiera haber trabajado Gámiz bajo la dirección de Guillén, pero no lo creemos. López de Gamiz permaneció en Miranda de Ebro hasta la contratación del retablo de Santa Clara. El retablo de Santa Clara de Briviesca difícilmente se puede comprender desde la evolución de la obra de Guillén, más interesante que la del mirandés, ni desde una supuesta evolución genial de la obra de López de Gámiz. La escultura de Santa Clara representa el más espectacular desarrollo de una nueva concepción plástica directamente derivada de la obra de Miguel Angel. Ni Guillén ni López de Gámiz tuvieron formación italiana y es inimaginable que desarrollaran tan tempranamente el nuevo estilo artístico.

Ni la obra de Guillén ni la de López de Gámiz permiten comprender, por sí mismas, la escultura y la arquitectura del retablo de Santa Clara. Hasta 1560 López de Gámiz sólo había realizado obras menores en Miranda de Ebro y en pequeñas poblaciones de su entorno: Santa Gadea, Bardauri, Zuñeda - un pequeño retablo dedicado a San Miguel que tasó Guillén en 1559, llamado por los representantes parroquiales- y Salinillas de Buradón (Alava). Todavía en 1562 atendía, con un desconocido Pedro de la Estrada, el retablo de San Martín de Losa.

Las grandes obras de López de Gámiz se realizaron de 1564 a 1570. El 6 de octubre de 1564 ofreció fianza sobre la realización del retablo de Estavillo (Alava). Días antes lo habría contratado ${ }^{10}$. Entre los fiadores aparece Bernardo Trincado que a partir de 1569 fue mayordomo del Condestable en las obras de Briviesca. Estavillo pertenecía al señorío del Condestable. Este retablo, próximo a los retablos riojanos de Arnao de Bruselas, supone el conocimiento de la obra de Briviesca y Astorga. Para entonces Pedro de Arbulo había regresado a Briones (La Rioja) después de trabajar en Astorga a las órdenes de Becerra. También se encontraba en esta zona Juan Fernández de Vallejo ${ }^{11}$.

A finales de 1564, Gámiz contrató un retablo en Vallarta y al año siguiente, otro en Valluér-

\footnotetext{
10 Se suele dar la fecha de 1561 para el comienzo de las obras. Retrasamos el retablo a 1564 pues las fianzas seguían con mucha inmediatez al contrato. Se acabó en 1567.

1 La relación del retablo de Estavillo con el de Lanciego, obra de Fernández de Vallejo, en Barrón García, A., "Juan Fernández de Vallejo en Lanciego y Obécuri» en Sancho el Sabio, n. ${ }^{\circ}$ 6, 1996, pp. 339-356.
} 
canes. Concluyó el retablo de Bardauri en 1567. Distintos colaboradores le ayudaron, incluidos artistas que trabajaban en los retablos de Briviesca. Los retablos de Estavillo y Vallarta son obras muy interesantes y de gran calidad pero distan de la excelencia de las obras de Briviesca; basta comparar las escenas del lavatorio y la última cena. Más se alejan los retablos mayores de Bardauri y Valluércanes. El equipo que levanta este último retablo es tan descuidado, y el resultado tan deficiente, que Vélez Chaurri no lo reconoce y le supone perdido.

Simultáneos al retablo de Santa Clara son el retablo de Santa Casilda en la colegiata de Briviesca - concluido para agosto de 1567- y, posiblemente, el retablo del monasterio de Vileña y aún el de los Mateo de Ezcaray. Son obras magníficas en las que Gámiz contó con el mismo equipo de colaboradores de Santa Clara. El retablo de Santa Casilda, así como buena parte del retablo del monasterio de clarisas ha de corresponder a Juan de Anchieta ${ }^{12}$. Aunque la documentación se resiste a aclararlo, la relación estilística es evidente y así se ha repetido muchas veces por diversos autores. Nos parece que no es preciso que aparezca confirmación documental para devolver las obras a su autor material. Vemos los mismos tipos humanos, composiciones coincidentes, la misma excelencia, aunque en este punto sólo podemos repetir los indicios documentales que se han publicado. Desde 1564 Anchieta estuvo vinculado sentimentalmente con una burgalesa. Tuvieron un hijo natural que fue bautizado en Valladolid en enero de 1565. Las idas y venidas de Anchieta de Valladolid a Briviesca debían ser frecuentes y Juan Bautista Beltrán pudo querer precisar en qué momento le había anticipado un dinero que le debía el guipuzcoano al señalar que le había entregado 96 reales "quando se fue agora la postrera vez a Birbiesca». Era verano de 1569 y poco después Gámiz aceleraba la conclusión del retablo. Anchieta no tenía recursos propios y pudo estar al servicio de Guillén y de López de Gámiz sucesivamente. Posiblemente se había formado en el taller de Juan de Juni. El maestro se acordó de él al testar. Por encima de la natural inclinación filial hacia Isaac de Juni, recomendó a Anchieta como el más idóneo para proseguir el retablo de Santa María de Medina de Rioseco que había que realizar a partir, precisamente, de una traza de Becerra. Juni escribía su última voluntad en 1577 y, desde hacía años, Anchieta trabajaba en su tierra vasca natal. No es fácil que Juni conociera la obra que Anchieta había realizado como artista independiente en Zaragoza, Asteasu, Zumaya y Azcoitia, pero, además de acordarse de los años que pasó el vasco en Valladolid, había tasado el retablo de Santa Clara -donde suponemos que intervino Anchieta- asignándole un altísimo valor y quedando gratamente impactado, como demuestra su obra final.

Después de 1570, finalizadas las obras de Briviesca y disuelto en consecuencia el grupo de colaboradores, el genio de López de Gámiz se desvanece. Que se sepa, apenas contrató nuevas obras - relicario de Zambrana, retablo del licenciado Poza en Valluércanes, retablo de IrcioLa ejecución dista mucho de los grandes retablos de Briviesca. Por el contrario, son años en los que florece la escultura de una pléyade de artistas que debieron completar su formación en Astorga y Briviesca: Anchieta, Arbulo, Fernández de Vallejo y Ruiz de Zubiate entre otros. Sin negar la participación real de López de Gámiz en las obras mencionadas, se tiene la impresión de que el mirandés capitalizó un fabuloso equipo de artistas reunido en torno a las obras de Santa Clara.

12 Sobre Juan de Anchieta: Camón Aznar, J., El escultor Juan de Ancheta. Pamplona, 1943. No duda de la participación de Anchieta en Briviesca. Le atribuye el retablo Gómez Moreno, M., La escultura del Renacimiento en España. Barcelona, 1931. Sobre la relación de Anchieta y Briviesca, entre otros: Martí y Monsó, J., Estudios histórico-artísticos relativos principalmente a Valladolid. Valladolid, 1901. Weise, G., Spanische Plastik aus sieben Jahrhunderten. Reutlingen, 1927, t. II/1. Ídem, Die Plastik der Renaissance und der Frühbarok im Nörlichen Spanien. Band II. Die Romanisten. Tubingen, 1959. García Gainza, M. ${ }^{a}$ C., "El escultor Juan de Anchieta en su cuarto centenario (1588-1988)", en Príncipe de Viana, n. ${ }^{\circ}$ 185, 1988, pp. 443-468. Martín González, J. J., «La estancia de Juan de Anchieta en Valladolid", en Príncipe de Viana, n. ${ }^{\circ}$ 185, 1988, pp. 469-476. Echeverría Goñi, P. L.; Vélez Chaurri, J. J., «López de Gámiz y Anchieta comparados... 

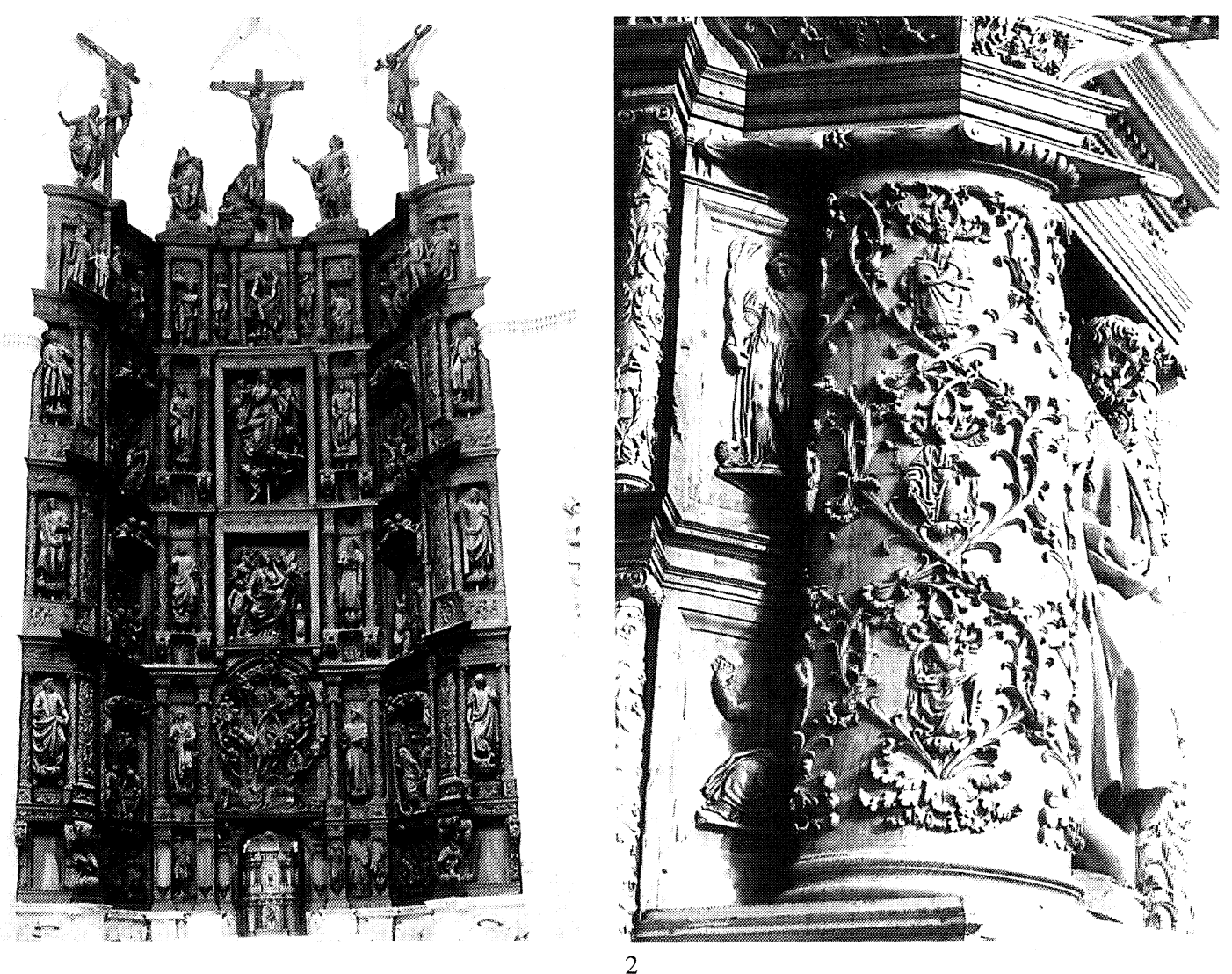

4

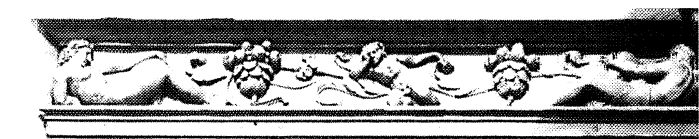

3
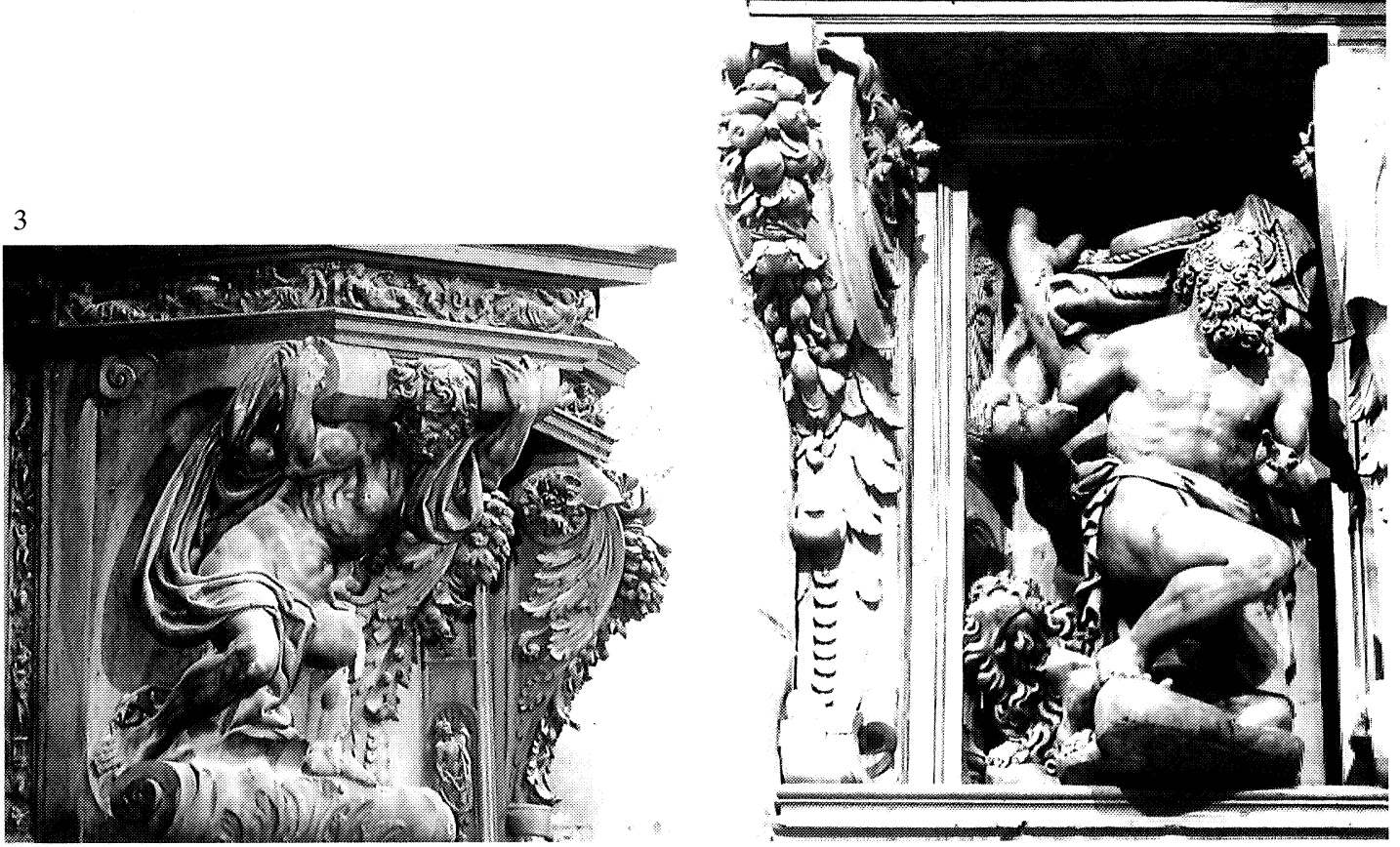

Fig. 1. Retablo mayor. Monasterio de Santa Clara, Briviesca (Burgos).

Fig. 2. Columna jónica proyectada al bies, primer cuerpo. Monasterio de Santa Clara, Briviesca (Burgos).

Fig. 3. Adán, en el banco. Monasterio de Santa Clara, Briviesca (Burgos).

Fig. 4. San Jerónimo, en el banco. Monasterio de Santa Clara, Briviesca (Burgos). 
Diego Guillén hubo de abandonar la traza del retablo original con conocimiento del patrón de las obras pues supuso un cambio radical. El cambio hubo de ser anterior a 1559, durante el patronazgo de Pedro Fernández de Velasco, pues, de haber ocurrido posteriormente, el Condestable que le sucedió no podía haber argumentado en el pleito desconocer el abandono de la traza primitiva. Hemos destacado que las monjas y representantes del hospital pidieron las cuentas desde 1557, fecha probable del inicio del retablo. Esta fecha ayuda a comprender las novedades estilísticas que introdujo el retablo, injustificables en el ambiente burgalés si no se conocía el nuevo estilo introducido por Becerra. Basta observar las ajustadas trasposiciones de las composiciones de Miguel Angel que ofrecen algunas figuras o las rebuscadas y refinadas proyecciones de los capiteles en las columnas al bies para confirmar que se trata de una obra sin precedentes hispanos y que se inspira directamente en lo italiano.

Precisamente Gaspar Becerra estuvo en Burgos en diciembre de 1557. En Burgos se estableció el platero italiano Jerónimo Genoa -o Jerónimo Corseto- relacionado con Becerra y platero del cardenal Francisco de Mendoza. La llegada de Becerra a Burgos podría estar relacionada con la toma de posesión del obispado por parte del cardenal Francisco de Mendoza y Bobadilla ${ }^{13}$. El cardenal, que había residido largamente en la Curia pontificia y había gobernado la ciudad de Siena por encargo de Felipe II, entró en Burgos el 21 de noviembre de 1557. Unos días después, el 1 de diciembre, está documentado Becerra en Burgos. En los años siguientes algunos artistas establecidos en Burgos, como el pintor italiano Pedro Antonio y el platero genovés Jerónimo Corseto, son llamados pintor y platero del cardenal.

Podría suceder que el retablo de Santa Clara se hiciera siguiendo una traza de Becerra -la planta que se menciona en la documentación. Aunque dirigido por Guillén y López de Gámiz sucesivamente, pudieron seguirse dibujos muy precisos de Becerra y cabe la posibilidad de que trabajaran italianos de su círculo. En Burgos contrataron diversas obras Giulio Sormano, Angelo Bagut y Bartolomé Carlone que posteriormente trabajaron para Felipe II en el ambiente de Becerra. La relación con Burgos pudo nacer en Briviesca.

El retablo del monasterio de Santa Clara en Briviesca obedece a una traza única desde el banco pétreo al remate. En el banco de piedra se disponen las caras de forma que siguen las inflexiones de las calles del retablo. Las columnas que separan la calle central se levantan sobre ménsulas de piedra decoradas con cabezas de águila semejantes a las de las ménsulas del tercer cuerpo del retablo y son iguales a las que usó Becerra en Astorga y en el retablo de las Descalzas Reales de Madrid. El eje de las originales columnas al bies (Fig. 2) coincide con las águilas desplegadas al viento en el banco pétreo. El concepto unitario del retablo permite suponer que se siguió un mismo plan por parte de los dos contratantes: la planta que tenía Guillén y que se debía dar a Gámiz al contratar el retablo. Suponemos que el genio de Becerra no es ajeno a esta planta.

Desde el punto de vista plástico, la escultura en piedra del retablo -aunque deteriorada por el tiempo- muestra fuerte semejanza con las imágenes del retablo. Algunas imágenes presentan un tratamiento formal más suave e idealizado. Pueden deberse a la participación de Guillén. Nos referimos a las escenas de la Oración en el Huerto y al Prendimiento así como a las imágenes de Santa Casilda, San Francisco e Isaías en el banco pétreo. Estas figuras ofrecen una notable dulzura expresiva. Por el contrario, otras figuras del banco muestran rasgos claramente romanistas, como la ceñuda figura de San Jerónimo cuyas barbas derivan del Moisés. Característica imagen romanista es una pequeña figura de una santa mártir con palma; de grueso cuello y musculosos

13 Archivo Catedral de Burgos, Registro 51, Actas 1556-1559, fol. 272r. Había sido nombrado obispo de Burgos en 1550, pero no tomó posesión del obispado hasta el 21 de noviembre de 1557, al regresar de Italia. Sobre Corseto, Barrón García, A., "Jerónimo Corseto y Pedro García Montero, plateros», en BSAA, t. LXII, 1997, pp. 359-377. 

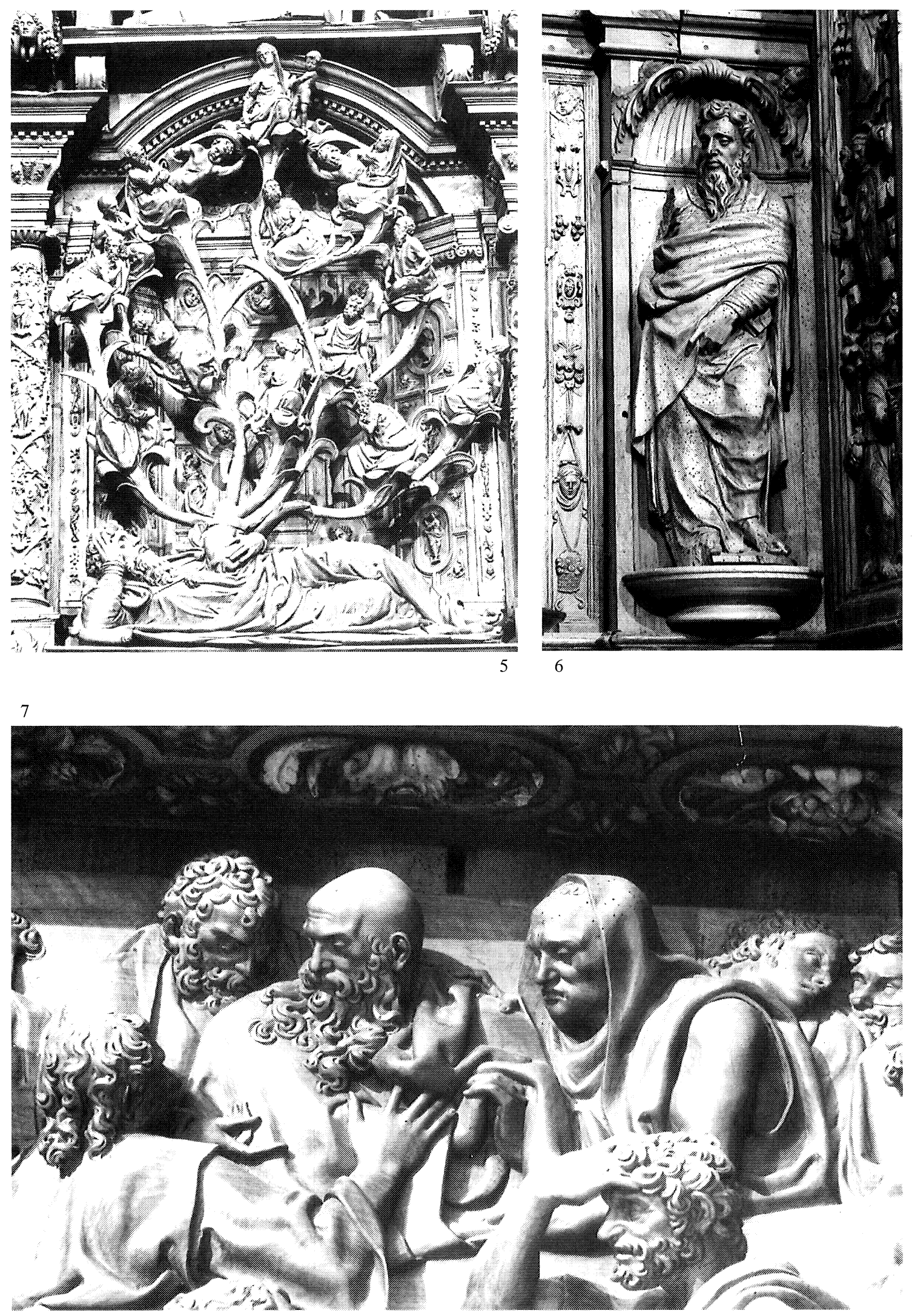

Fig. 5. Diego Guillén. Sueño de Jesé. Primer cuerpo. Monasterio de Santa Clara, Briviesca (Burgos).

Fig. 6. Diego Guillén. San Marcos. Banco. Monasterio de Santa Clara, Briviesca (Burgos).

Fig. 7. Lavatorio, detalle en el banco. Monasterio de Santa Clara, Briviesca (Burgos). 
brazos enseña los pechos y lleva ceñido un sostén semejante al que viste la hermosa figura de Eva soportando el retablo.

En el retablo de nogal también se puede encontrar la intervención de Guillén. Las pequeñas figuras exentas del banco se colocan bajo veneras del tipo de las que usaba Guillén. Lo mismo se puede decir del arco que protege la custodia o relicario. De las veneras más próximas a la custodia cuelgan las características algas de su estilo. Estas hornacinas aveneradas pueden ser interpretación personal de Guillén de una traza que no las contemplaba. De hecho la figura más próxima a Eva, hoy perdida, se disponía sobre respaldo liso, sin hornacina ni venera, a diferencia de la escultura vecina. Algunas de las figuras conservadas del banco pueden ser de Guillén, particularmente San Juan Evangelista -a perdido el rostro, pero la composición y las guedejas del cabello recuerdan la obra del burgalés - así como San Marcos (Fig. 6), del que se ha desprendido el atributo identificativo. También creemos suya la figura recostada de Jesé que repite el rostro de un evangelista del banco.

Evidentemente, López de Gámiz también trabajó directamente en el retablo, pero su estilo nos resulta difícil de precisar a la vista de la diferente calidad de lo que contrató. En lo mejor del retablo, que relacionamos con Anchieta, el expresivo estilo juniano se funde con la grave solemnidad de Becerra (Figs. 3 y 4). La escultura, tanto en lo formal como en lo espiritual, deriva de Miguel Angel. Son figuras de concepción monumental, músculos en tensión, cabellos aborrascados, rostros arrogantes de intensa vida interior, expresión desesperada y gesticulación sombría. Un apasionamiento contenido y doliente agita las figuras, aunque el ademán es moderado (Figs. 5 y 7 ).

Las poses rebuscadas, las fuertes musculaturas y la ornamentación recuerdan las figuras de la Sala Paolina de Castel Sant Angelo diseñadas por Perin del Vaga y acabadas por algunos artistas con los que trabajó Daniele da Volterra en Trinità dei Monti y que conoció Becerra en Roma ${ }^{14}$. La Asunción, incluido el círculo inferior de ángeles, que Volterra pintó en la capilla Rovere de la citada iglesia romana es muy semejante a la composición del mismo tema en Briviesca y Astorga. La exuberancia ornamental del retablo de Santa Clara de Briviesca, que no debería sorprender ni interpretarse como resabio plateresco, se encuentra directamente relacionada con el decorativismo y la gracia dibujística del círculo de Perin del Vaga que habían frecuentado artistas con los que contactó Becerra: Marco Pino, Girolamo Siciolante y Pellegrino Tibaldi (Figs. 8 y 9).

La hipotética relación del retablo de Santa Clara con Gaspar Becerra la había establecido Antonio Ponz en el siglo xviII; la tuvo por buena Ceán Bermúdez y, mas tarde, Isidoro Rosell ${ }^{15}$. Si se compara el retablo de Astorga y el dibujo del retablo de las Descalzas Reales con el retablo de Santa Clara se pueden encontrar muchos puntos en común, tanto en la traza como en el detalle decorativo. Destacamos las semejanzas iconográficas y compositivas en las figuras, las imágenes de virtudes y niños dispuestos en par, el exuberante adorno de columnas y frisos con coincidencias en el detalle muy llamativas, las limpias y profundas portadas que enmarcan los encasamentos, las figuras recostadas sobre las vertientes de los frontones, las molduras de cueros recortados y niños intercalados, los mascarones del basamento de las columnas, las águilas-ménsula del banco, y la monumentalidad clásica de las custodias que se conciben como solemnes templetes exentos.

\section{$* * *$}

14 Calí, M., De Miguel Ángel a El Escorial. Momentos del debate religioso en el arte del siglo XVI. Madrid, 1994, pp. 285-286.

15 Rosell y Torres, I., «El retablo de las Descalzas Reales, obra de Gaspar Becerra», en Museo Español de Antigüedades, t. V, 1875, p. 536. 


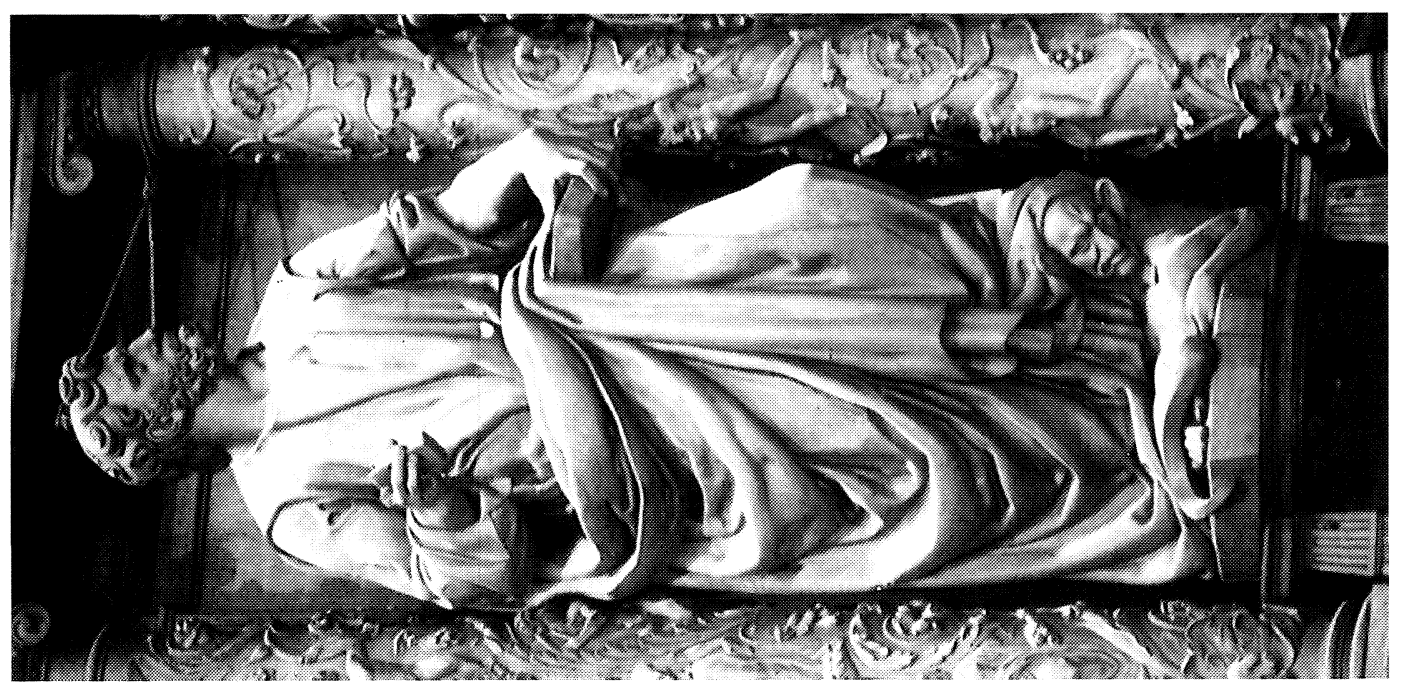

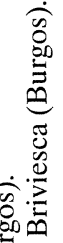

a

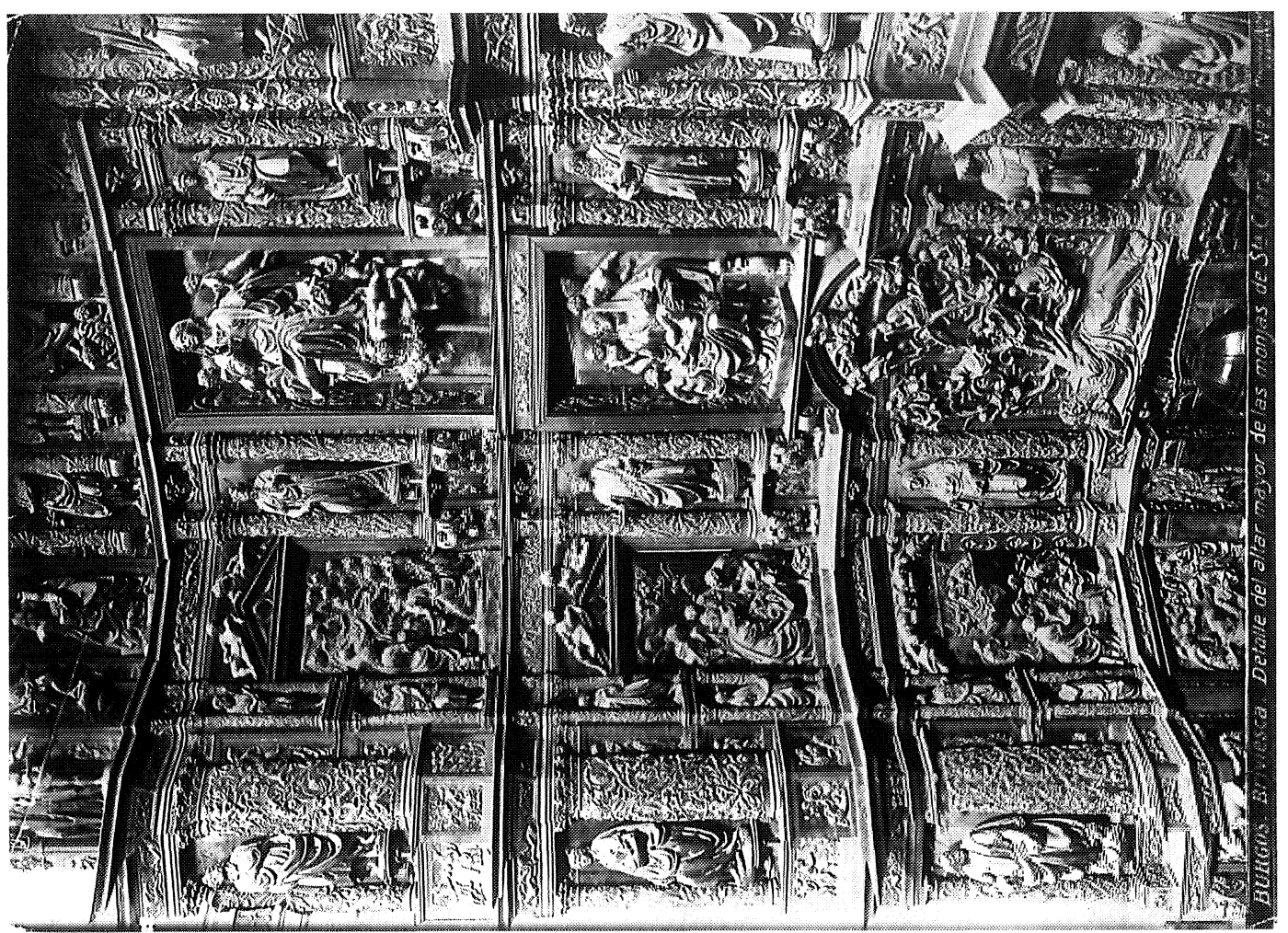

$\infty \quad \frac{0}{0}$

$\sum$

离

ปัป

응

ฐ

¿

北 步 


\section{Apéndice documental}

1572, aprox. El procurador del Condestable de Castilla, Iñigo Fernández de Velasco, presenta ante el juez alegaciones contra Pedro López de Gámiz por el retablo de Santa Clara de Briviesca.

Archivo Foral de Bizkaia, Judicial-Corregimiento, leg. 1.352, n. ${ }^{\circ} 42$.

Ilustre señor: En el pleito que v.m. tiene visto entre don Iñigo Fernandez de Velasco, Condestable de Castilla, como patron del monasterio de Santa Clara de la villa de Virbiesca, con Pero Lopez de Gamiz, ymaginario, por parte del dicho Condestable y monasterio se suplica a v.m. sea fuido traer a la memoria lo siguiente:

Lo primero que habiendose concertado el dicho Condestable con Diego Guillen para que hiziese en el dicho monasterio un retablo, conforme a cierta traça que dio pintada en un papel -el qual habia de ser de valor de hasta mil y quinientos o mil y seiscientos ducados y no mas-, despues de haberla començado se murio. Y el dicho Condestable se concerto de nuevo con el dicho Pero Lopez de Gamiz para que prosiguiese y acabase el dicho retablo, conforme a la dicha traça que Diego Guillen dejo hecha en el papel; y se obligo a pagarle a ciertos plaços segun y como la obra fuese tasada. Por manera que, aunque en el concierto que con Diego Guillen se habia hecho se puso preçio tasado a la obra para que de alli no pudiese subir y que se habia de guardar la traça, con el dicho Pero Lopez de Gamiz no se le puso tasa al valor del retablo sino lo que fuese tasado por oficiales, con que siempre se capitulo y asento que habia de seguir y guardar la traça del dicho Diego Guillen, la qual, para este efeto, habia de entregarsele, como pareçe por la escritura que de ello otorgaron a 2 de março de 1566; la qual despues tornaron a otorgar y ratificar añadiendo algunas cosas en 4 de otubre de 1569.

Lo segundo que el dicho Pero Lopez de Gamiz, debiendo seguir la dicha traça que le estaba dada, hizo el retablo tan conforme a su voluntad que en ninguna cosa la siguio; tanto que dicen todos los tasadores que para ello fueron nombrados, en lo qual todos se conforman, que el dicho retablo en ninguna cosa se pareçe a la traça ni la traça al retablo; y que hizo en el, aun conforme al intento que llevo, muchas cosas inpertinentes y costosas y en lugares ascondidos donde no es posible verse; y si se hiziera conforme a la traça, aunque estubiera en toda perfecion, no podia subir de tres mil ducados; y ansi, que de hazerse de una manera o de la otra, recibe de daño el monasterio si ... el retablo como esta y pagarle mas de [roto] / ...en los estrados que el retablo no esta hecho conforme a la traça de Diego Guillen, estando como estaba obligado a seguirla no ay obligacion para que el Condestable le reciba ni se le pague [tachado: porque no se pudo apartar de la dicha traça] quem ad modum em[ere] non pot[ui] recedi ab arbitro cuius arbitrio opus est perficiendum ut in 1 [ege] si quis arbitratu et 1 [ege] cum stipulatus sim mihi oprocule ff[fecerum] de verbo obliga l[ege] mulcta $\mathrm{ff}[$ fecerum] de condi[cione] et demonstra[tione] ita etiam recedi non pot[ui] a lege dicta in edificando et quod $v$ legem factum est non est idem 1 [ege] cum in plures gs lege dicta ff[fecerum] locati. Y como sea diferente lo que da Pero Lopez de Gamiz de lo que con el se capitulo pues pudiera pedirsele la pena, si la hubiere puesta, por no seguir la traça, o el interese no habiendo pena, ut in dictis legibus, muy mejor conpetera excepcion para no tomar el retablo por ser, como este es, el interese del Condestable y su monasterio $\mathrm{q}[\mathrm{ua}] \mathrm{re}$ cuidamus actionem multo melius exceptionem ut in regula juris. $\mathrm{Y}$, en efecto, siendo diferente de lo capitulado, es dar una cosa por otra; y no puede ser el Condestable compelido a que la reciba q[ua]re aliud pro alio solvi non pot[ui] et l[ege] 2 gs $1 \mathrm{ff}[$ fecerum] si cer[ta] petat l[ege] eum aquo 1[ege] de solu[tione]. Y si se diese que el Condestable fuese compelido a tomar el retablo y pagar lo que vale conforme a la tasacion, seria hazerle comprar lo que no quiere ni trato quod fieri non pot[ui] cum invitus emere nemo compelatus 1 [ege] nec emere 1 [ege] de jure de lib[ertate]. Y esto es tan llano que en ello la parte contraria no duda y solamente pretende no haber sido obligado a seguir la traça por muchas razones que allega a las quales se satifara en particular.

Et primo non obstat decir que no tiene obligacion a seguir la traça de Diego Guillen; atento que, quando el dicho Diego Guillen murio, dejo hechos los dos primeros vancos del retablo de quatro que habia de tener, en los quales dice que Diego Guillen no habia guardado su propia traça. Y que el no se obligo a hazer conforme a ella, sino a la planta que Diego Guillen tenia hecha la qual era diferente de la traça, para lo qual pondera el capitulo primero de la escritura, en la qual ninguna cosa se dice de traça sino que hara [roto]

... aun no por eso se arguye sciencia del Condestable en la mudança de la traça. Ni quedo obligado a tomar el retablo y pagarle. Lo uno porque decir Pero Lopez de Gamiz que valdria doce mil ducados no prueba que de cierto tubiese tal valor. Antes, considerado que era el quien le hazia y la estimacion en que los oficiales tienen sus cosas, pudo el Condestable verisimilmente creer que no valdria la mitad. Y como ponerle nombre Pero Lopez de Gamiz no hazia que fuese de tanto valor. Y porque acabado habia de tasarse y pagar solamente lo que valiese et sic sciebat jus suum durare no se pre judico porque Gamiz lo estimase en mucho 
$\arg [$ ento] tax[ato] in 1[ege] sicut gs non videtur ff[fecerum] qui mo[do] pign[ore] vel supo[sui] solvi. Lo otro porque, como esta presupuesto al principio, aunque en la obra que habia de hazer Diego Guillen se puso traça y precio tasado, pero en las contrataciones hechas con Gamiz no ay mas de que se guarde la traça y el precio como se tasare por oficiales. Y ansi pudo muy bien ser que guardando la traça fuese de mucho valor por la mas perfecion que podia tener hecho por mano de un artifice que de otro. Pero pues Gamiz no guardo la traça, como era obligado, no ay que tratar de lo que vale por tasacion, que si la guardara aqui confesamos y nos allanamos que el Condestable tubiera obligacion a pagar todo lo en que el retablo se tasase. Y con esto tambien se responde a lo que Pero Lopez de Gamiz dice que, pues se le dieron cinco mil ducados antes de acabar la obra, se ha de creer que el Condestable supo que lo valdria. Y mas porque pudo ser que tubiese tanto valor y que se le hubiese de pagar guardando la traça pero, no la guardando, no ay obligacion para pagar no solo mas de los cinco mil ducados que tiene recibidos pero ni aun a tomar el retablo por ellos. Y porque tambien Pero Lopez se obligo que, hecha la tasacion del retablo, si fuera tasado en menos de lo que el tubiese recibido [roto] / ...ya no se reparaba en el precio, porque confesamos ser ansi que quanto a Pero Lopez de Gamiz no hubo precio cierto sino el que se tasase. Y antes esta se retuerce contra el mismo Gamiz, porque si habiendo excedido de la traça Diego Guillen - como el dice- y habiendo dejado hecho casi la mitad del retablo, porque quedaron acabados los dos primeros vancos, no valio mas de quinientos mil maravedis en que el mismo lo taso, como es posible que, aunque el no estubiera obligado a seguir la traça sino la planta -como pretende quod tum negamus-, haya excedido tanto en la otra mitad que sola ella valga diez mil ducados. Porque si guardara la planta y conforme a ella hiziera lo que faltaba, aunque no guardara la traça, conforme a su misma tasacion valiera lo que el hizo otros quinientos mil maravedis o poco mas, pero un exceso tan grande es cosa agena de todo buen entendimiento que no sea exceso y hecho contra voluntad y sin noticia del Condestable y fuera de lo contratado y capitulado.

Y la pretension de Pero Lopez de Gamiz no se puede justificar por decir que queda perdido, pues esto no ha de bastar para condenar al Condestable si no esta obligado; quanto mas que ningun daño verna a recibir porque es cosa cierta que puede gastar las pieças de este retablo en otras obras que tiene a cargo y venderlas, cada una de por si, sin daño alguno. Y quien verdaderamente viene a ser damnificado es el hospital y monasterio, que le ha de pagar, haziendole tomar una cosa que no compro ni puede pagar, porque no tiene hazienda para ello. Y aunque parezca que esta paga no se a de hazer toda junta sino trescientos ducados cada año, conforme al ultimo contrato, pero no esta en solo esto el daño sino en que, lo que por el pagare el monasterio, no le es de probecho alguno si no se dora y estofa; y estofandole ha de pagar otros doce mil ducados que por lo menos costara como esta probado; que es lo uno y lo otro mucho mas que el capital de la dotacion del dicho monasterio; por manera que si se tomase el retablo ha ... pero ni hazienda para sus [roto].»

[Hoja suelta:] Porque a esto se responde que a esta condiçion del preçio puesto por el dicho maese Guillen no se obligo ni por pensamiento el dicho Gamez; y demas que esto se colige claramente de las palabras de las dos escrituras hechas por el dicho Gamez era ymposible que se obligase a esto porque en la primera escriptura de Gamez se dice que los dos vancos que avia hecho el dicho maese Guillen se avian tasado en quinientos y [roto] mil maravedis, que son los dichos mil y quinientos ducados poco mas o menos, y era mucho mas lo que estava por hazer. Por manera que no se puede deducir de lo susodicho sino que el dicho Gamez solamente se obligo a hazerlo conforme a la dicha traça pero no a que toda dicha obra no excederia del dicho preçio pues esto era ymposible [roto]. [Dice que por Gámez no esta probado ni aun articulado que lo hubiese tratado con el Condestable]. Lo otro porque tampoco se colige esta voluntad del Condestable por deçir que algunos criados suyos veian hazer la dicha obra; lo uno porque, aunque la viesen hazer, no se sigue que savian la traça que estava dada; y aunque la supieran, no pudieron juzgar si exçedia o no porque no eran ofiçiales. Y lo otro porque, aunque ellos lo vieran y supieran y entendieran, no por eso se seguia que lo savia y entendia el dicho Condestable que residia y estava mas de treinta leguas de alli y asi la dicha probança por muchas raçones no es concluyente. Lo otro porque tampoco se prueba que el dicho Condestable quisiese alterar la dicha traça [Roto]. 